УДК: 811.163.41’37

811.163.41'367.62

81:008

https://doi.org/10.18485/kij.2017.64.1_2.9

ВЕСНА С. НИКОЛЙ

Универзитет у Београду

Филолошки факултет
Оригинални научни рад

Примљен: 09.03.2017.

Прихваћен: 15.04.2017.

\title{
ЛИНГВОКУЛТУРОЛОШКА СЛИКА КУЋЕ У РЕЧНИЦИМА СРПСКОГ ЈЕЗИКА
}

\begin{abstract}
Циљ рада јесте да се анализом системског (речничког) материјала - дефиниција, примера употребе, синонима, деривата и фразеологизама - открије лингвокултуролошка слика куће у српској културној заједници, односно да се утврди које су се све културне информације наталожиле у семантичком садржају лексеме кућа током њене дуготрајне и учестале употребе. Анализом података које различити речници српског језика доносе може се много тога открити не само о лексемама и њиховом месту у лексичком систему већ и о култури, менталитету и ставовима његових говорника, тако да рад уједно представља и пример употребе једнојезичних речника у лингвокултуролошке сврхе.
\end{abstract}

Кључне речи: српски језик, лингвокултурологија, речници, лексема кућа.

\section{1. Уводна разматрања}

1.1. Предмет рада и циљеви истраживања. Живот човека је од најранијег детињства везан за кућу и својим највећим делом одвија се у њој. У питању је простор у којем човек живи са својом породицом и у којем задовољава своје основне биолошке, друштвене и емотивне потребе. Кућа није цивилизацијска тековина новијег датума, већ је одувек неодвојиви део човековог живота. Кроз историју цивилизације мењао се изглед куће, материјали од којих је грађена, као и технике у изградњи, али не и њена основна функција. Појам куће је суштински наднационалан и универзалан, док су разлике које међу кућама постоје условљене социјалним, географским, историјским и културним приликама. Због свега наведеног, лексема кућа спада у најстарији и најужи лексички фонд сваког, па и српског језика. Лексеме које у овај фонд улазе имају најбогатије полисемантичке структуре и велики број деривата, што је случај и са лексемом која је

*vesnanikolic88@gmail.com 
предмет нашег истраживања. Лексема кућа развила је у српском језику 26 значења и преко 160 деривата и јавља се у око 60 устаљених синтагматских спојева и фразеологизама. Поред тога, лексема кућа ступа у различите синтагматске и парадигматске односе са другим лексемама, чиме се проблематика истраживања додатно усложњава. Чињеница да појам куће спада у групу основних егзистенцијалних појмова изразито утемељених у нашем свакодневном искуству условила је изузетну културну потентност њене језичке ознаке. Циљ рада јесте да се на основу различитих речника српског језика: дескриптивних и специјалних (речника синонима, речника жаргона, фразеолошког речника и сл.) открије како се представа куће концептуализује у савременом српском језику, као и које су се све културне информације наталожиле у семантичком садржају лексеме кућа током њене дуготрајне и учестале употребе. Реконструкција језичке слике куће откриће нам и место које овај појам заузима на аксиолошкој лествици носилаца српског језика, што је за ово лингвокултуролошки усмерено истраживање од посебне важности, будући да желимо да покажемо да кућа није обична, неутрална лексема у српском језику, већ врло важан културолошки концепт. У раду се преплићу лексиколошки и лингвокултуролошки подаци и закључци, а све у циљу добијања што потпуније слике концепта куће у савременом српском језику.

1.2. Преглед литературе. На српском лингвистичком простору је о лексеми кућа са лингвокултуролошког становишта мало писано, односно ова лексема није била самостални предмет културолошки заснованих истраживања. Међутим, приличан број података о месту дате лексеме у језичкој слици света говорника српског језика можемо добити из радова Стане Ристић, која је са различитих становишта проучавала поимање дома у српском језику. Она се у својим радовима бавила концептом ДОМА у религијском и књижевном дискурсу (Ристић 2013б, 2013в), док је у коауторству са Иваном Лазић-Коњик (Ристић и Лазић-Коњик 2012) испитивала аспекте концептуализације овог појма у српском језику уопште. Концепт ДОМА у српском језику није могуће разумети без узимања у обзир концепта КУЋЕ, јер се лексема дом заправо и дефинише преко лексеме кућа, што потврђује и примарно значење дома у Речнику САHУ: кућа као место где човек живи са својом породицом. Ова чињеница омогућила нам је да за потребе овог истраживања у радовима о поимању дома у српском језику и српској култури пронађемо драгоцене податке о културолошком концепту КУЋЕ. С друге стране, лексеми кућа је у српској лингвистици поклоњена значајнија пажња са лексиколошког становишта. Полисемантичка структура куће исцрпно је анализирана у раду Р. Марковић „Гранање значења речи које означавају кућу и њене делове”. Рад представља компаративну анализу полисемантичких структура лексема са основним значењем куће и њених делова у српском, руском и енглеском језику и изналажење сличности и разлика у метафоричком и метонимијском понашању датих лексема у наведеним језицима. Поред тога, лексема кућа је у лексиколошким студијама и радовима чест пример за различите лексичке појаве и односе (исп. нпр. Гортан-Премк 2011: 34-35, 130). Лексемом кућа у српском језику бавила се и Сања Ђуровић са Филолошко-уметничког 
факултета у Крагујевцу. Она је у свом магистарском раду - Деривацииони систем именица које означавају кућу и њене делове - извршила творбено-семантичку анализу деривационог гнезда лексеме кућа и именица које означавају њене делове. Поред тога, предмет научног интересовања С. Ђуровић био је и синонимски пар кућа : дом у српском језику (исп. Ђуровић 2013: 329-338).

1.3. Грађа. Грађу за рад представља материјал добијен из тезаурусног Речника српскохрватског књижевног и народног језика (Речник САНУ) ${ }^{1}$ и из различитих специјалних речника српског језика (речници синонима, речник жаргона, асоцијативни речници, речник фразеологизама и сл.). Због своје свеобухватности и исцрпности, Речник САНУ представља системски материјал који обухвата не само систем дефиниција лексеме кућа већ и њено творбено гнездо, карактеристичне синтагматско-синтаксичке спојеве, фразеологизме и примере употребе. Због свега наведеног, материјал тезаурусног Речника САНУ захвалан је за широко засновану анализу лексеме кућа, али и њених фразема, синонима и деривата.

\section{2. Речнички подаци о кући у савременом српском језику}

2.1. Полисемантичка структура лексеме кућа. Да бисмо видели како се лексема кућа концептуализује у савременом српском језику и да бисмо открили њен културолошки потенцијал, најпре ћемо кренути од њене дефиниције у Речнику $C A H У$, као нашем најисцрпнијем речнику. Циљ нам је да анализом богате полисемантичке структуре дате лексеме дођемо до података о начину поимања куће од стране говорника српског језика и о месту које она заузима у језичкој слици света носилаца нашег језика.

Полисемантичка структура лексеме кућа се, према Речнику САНУ, састоји из 26 значења, груписаних у 14 тачака. Богата полисемантичка структура ове лексеме последица је изразите утемељености њених десигната и денотата у свакодневно искуство говорника, што изазива велики број асоцијативних веза најразличитијих елемената стварности са кућом и њеним деловима (Марковић 1991: 55). Другим речима, кућа има велики друштвени, психосоцијални, егзистенцијални и емотивни значај у животу сваког човека, па је стога сасвим логично што су људи различите делове стварности која их окружује самеравали у односу према кући. На тај начин се полисемантичка структура дате лексеме непрестано богатила новим значењима. Сличан је случај и са другим лексемама које, попут именице кућа, припадају најстаријем и најужем лексичком фонду.

За примарно значење лексеме кућа изабрано је оно које у први план ставља физички и функционални аспект овог појма: грађевински објекат, зграда за пре-

\footnotetext{
${ }^{1}$ С обзиром на то да Речник CAНУ није завршен, за лексеме које у њему још увек нису обрађене коришћени су шестотомни Речник српскохрватског књижевнога језика (РМС) и једнотомни Речник српскога језика (РСЈ).
} 
бивање, становање или какву друштвену потребу. ${ }^{2}$ Из наведене дефиниције, међутим, мало тога можемо сазнати о кући. Осим чињенице да је у питању физички објекат („зграда”) са функцијом „за становање” или „какву друштвену потребу”, о кући нам ништа више није речено. Нема никаквих података о томе како прототипична кућа изгледа, од каквих се материјала најчешће гради, који су њени саставни делови који је разликују од других грађевинских објеката и сл. Проблем је у томе што су дефиниције у описним речницима обично научног и таксономског карактера, односно у њима се, због тежње ка конкретизацији и објективизацији описа, наводе само нужне дистинктивне значењске компоненте. Према речима J. Бартмињског (2011: 95), научни карактер дефиниција умањује њихову експликативну вредност, што је посебно очигледно код аутохтоне лексике која има развијену семантику, деривацију и фразеологију. Услед таквог поједностављеног дефинисања фундаменталног и сложеног појма као што је кућа, на основу значења које се у речнику наводи као примарно не можемо одговорити на питање како говорници српског језика заиста поимају кућу, односно не можемо одредити место куће у српској култури. Семантички садржај лексеме кућа састоји се из знатно више семантичких црта него што би се из дефиниције основног значења могло закључити. Далеко више података можемо добити анализом секундарних семантичких реализација именице кућа, као и из карактеристичних колокација и фразеологизама који следе иза система дефиниција. У недостатку лингвокултуролошког речника у ужем смислу, дефиниције лексема и примери који се уз њих наводе у једнојезичним речницима служе као важан извор културолошких информација.

Као што је на самом почетку речено, полисемантичка структура именице кућа обухвата 26 значења, али нису сва подједнако важна за њено осветљавање са лингвокултуролошког становишта. ${ }^{3}$ У трагању за одговором на питање како култура учествује у образовању концепта КУЋЕ од посебне су важности значења која упућују на поимање куће као породице, као и семантичке реализације настале активирањем семе колективне експресије нешто важно, неопходно.

${ }^{2}$ На исти начин, кућа је дефинисана и у Речнику српскога језика. Нешто другачији приступ, међутим, проналазимо у Речнику МС: грађевински објекат који има зидове и кров и служи обично за становање; зграда; просторије у којима се станује, живи, стан, пребивалиште. За разлику од друга два речника нашег језика, која акценат стављају искључиво на функционални аспект куће, Речник $M C$ при дефинисању дате лексеме у обзир узима и изглед прототипичне куће, односно делове из којих се она обично састоји. Најважнија функционална семантичка компонента примарног значења лексеме кућа према дефиницији датој у Речнику МС јесте место становањ $а$ (људи).

3 Занимљиво је да су, када је лексема кућа у питању, продуктивне, активне искључиво семе функције. Другим речима, за реализацију секундарних значења дате лексеме од пресудне су важности семе функције, док је изглед куће у потпуности занемарен, што је парадоксално када знамо да је људима у свакодневном животу итекако важно каква је кућа у којој живе, будући да она умногоме одређује њихову егзистенцију и социјални статус. Лексема кућа представља пример, како Р. Драгићевић констатује (2007: 76), разилажења животних и језичких приоритета. Из перспективе језика важно је само то да кућа представља оквир унутар којег се одвија живот човека, па су у развијању полисемантичке структуре активне једино семе функције. 
Да је кућа за кориснике српског језика много више од пуког грађевинског објекта који служи за становање, показују секундарне семантичке реализације у којима се овај, примарно физички, појам изједначава са породицом: родни, породични дом, домаће огњиште; породица; они који живе у једном кућанству, домаћинству, породична заједница, породииа; породица, род, лоза, династија (често са додатком породичног имена као ближег обележја); већа породична заједница (обично браћа са својим породицама), чији чланови живе на заједничком имању; заједница од више породица истог презимена, везаних пореклом од истог претка, братство. Дефиниције у речницима указују на то да је основ породичног живота заједништво (исп. породична заједница, заједничко имање, заједничко порекло и сл.), јер се кроз њега остварује присност међу укућанима и обезбеђује осећај јединства и сигурности. Примери који се уз дефиниције ових значења наводе пружају нам увид у стереотипе о подели улога у вођењу домаћинства и месту жене у патријархалном друштву: Човек се застрже у непрекидној борби ... док је жена везана више за кућу (Јак. С. 1. 10); Док су мужеви водили послове ... жене су седеле код куће (Милис.); Сока сама води кућу (Игњ. Ј. $10,30)$. Кроз наведене примере запажа се исказивање раширених ставова друштвене заједнице о жени као особи чија је једина улога у друштву обављање кућних послова, чиме се открива њен неравноправан положај у односу на припаднике мушког пола. Ипак, њен значај за опстанак и просперитет куће не доводи се у питање: Мој Боже, зна се, жена је кућа и раскућа (Божић, АСК 1995, 29).

Захваљујући томе што породица конотира присност, блискост и неку врсту међусобне повезаности њених чланова, из овог значења лексеме кућа развија се и једно значење које ниједан речник српског језика не бележи: клуб, екипа. Наиме лексема кућа се све чешће употребљава и у навијачком жаргону: $\underline{k \downarrow \hbar o, ~ c в и ~}$ на Маракану и Пун север, кућо (графити у Београду). Оваква употреба именице $\kappa y ћ a$ може се објаснити чињеницом да навијаче једног фудбалског клуба повезује љубав према својој екипи, због чега они навијачке групе којима припадају доживљавају као неку врсту заједнице или чак породице. Да се фудбалски клуб конципира као кућа, потврђује још један графит: Док не средимо ствари у својој $\kappa y \hbar u$, нећемо вас тући (графит навијача Партизана упућен навијачима Црвене звезде, у којем је лексема кућа употребљена у значењу „клуб, екипа”). Блискост међу члановима породице и члановима навијачких група послужила је као индуктор преношења номинације с једног појма на други (са куће на клуб).

За откривање односа говорне заједнице према одређеном појму од посебне су важности значења индукована активношћу семе колективне експресије. У овим семантичким компонентама ускладиштена су веровања и ставови једног друштва према различитим појавама и појмовима из ванјезичке стварности. Тако нам значење 6.a. назив од миља (обично у обраћању мајке детету, често са атрибутом моја) открива представу о кући као нечему врло важном, вредном и драгом. Дакле, реална важност куће утицала је на настанак наведеног секундарног значења лексеме којом је означена. Овакав доживљај куће у потпуно-

сти је очекиван, будући да је реч о месту где човек живи са својом породицом, 
обавља различите послове, задовољава своје биолошке и психолошке (интимне) потребе и које у животу сваког човека има изразиту вредност. Метафоричким повезивањем куће и детета наглашена је висока аксиолошка позиција оба појма у српској језичкој слици света. Кућа и деца (породица) спадају у групу основних егзистенцијалних појмова, заједно са мајком, земљом, народом и сл. Значај који кућа има за човека уградио се у виду семе колективне експресије у семантички садржај примарног значења лексеме кућа и управо је та потенцијална сема активирана у наведеном значењу (Драгићевић 2007: 76). Ово значење куће реализује се по правилу у вокативу једнине, и то најчешће у синтагматском споју са одређеним атрибутом: кућо моја, кућо стара. Поздрав кућо стара указује на присност, пријатељство.

Доживљај куће као нечег важног и неопходног могао би се сматрати извориштем за настанак значења место пребивања (село, град и сл.), родни крај, родна земьа, завичај, домовина, будући да је крај из кога се потиче високо вреднован код сваког човека. У овом значењу се концепт КУЋЕ проширује родољубивим елементима, иначе својственим концепту ДОМОВИНЕ.

О важности куће у националном менталитету Срба сведоче и примери из разговорног језика попут: Сваки положени испит ми је велики као кућа. У еталону ${ }^{4}$ из наведеног примера - велики као кућа - важност испита пореди се са важношћу куће, чиме је још једном потврђена њена висока позиција на аксиолошкој лествици говорника српског језика.

Да представа куће у српској лингвокултури није увек идилична, показују нам примери попут На моја је леђа пала сва кућа (Коч. 5, 112). У овом примеру видимо да се кућа понекад концептуализује као терет који човек мора носити на својим леђима. Овакав доживљај куће проузрокован је обавезама које она изискује. Кућа јесте место на којем човек у окриљу породице налази топлину, мир и сигурност, али је, са друге стране, за њено стицање и унапређивање потребно уложити много рада и труда. Када кућу доживљавају као тежак терет на леђима, говорници имају на уму обављање кућних послова, обезбеђивање егзистенције за породицу и свега што је потребно за несметано функционисање домаћинства.

Видимо да је честа и дуготрајна употреба лексеме кућа довела до тога да се у њеном семантичком садржају наталоже бројне културолошке информације, што наши једнојезични речници и региструју кроз дефиниције семантичких реализација одреднице кућа и примере којима се издвојена значења поткрепљују.

2.2. Лексема кућа у фразеологизмима. На фразеологију се у науци одавно гледа као на један од најважнијих извора за реконструкцију језичке слике света, због тога што се фразеологизми понашају као изузетно повољна „спремишта” за различите културне садржаје (Мршевић Радовић 2008: V-VI). Фразеологизми нам пружају много више података о вишедимензионалности представе куће у језичкој слици света говорника српског језика него што је то случај са семан-

${ }^{4}$ Еталонима се мере својства и особине предмета и појава и они се могу разликовати од културе до културе (в. Драгићевић 2010: 10). 
тичким садржајем идентификованим системом дефиниција. Разлог томе треба тражити у чињеници да дефиниције у описним речницима теже објективизацији и конкретизацији, чиме се занемарује сфера субјективних осећања и вредности које кућа има за говорнике. Емотивни и психолошки значај који кућа има за сваког представника говорне заједнице уграђен је у сему колективне експресије, активирану у бројним фразеологизмима. Када се говори о номинационој функцији фразеолошких јединица, често се у литератури користи термин „индиректна номинација", при чему се мисли на номинацију посебне врсте коју, поред именовања, прати експресивност (Мршевић Радовић 1987: 17). Управо ова чињеница чини фразеологизме са лексемом кућа материјалом погодним за анализу начина поимања овог појма у српској лингвокултури. Они нам помажу да откријемо не шта лексема кућа значи у српском језику, већ како је говорници разумеју и какав однос имају према њоме означеном појму.

У основи свих фразеологизама са кућом лежи представа о кући као нечему врло важном, неопходном. Ова потенцијална сема колективне експресије из примарног значења лексеме кућа, чијом су активацијом настала нека од секундарних значења ове лексеме, инхерентно је присутна и у фразеологизмима, који се након система дефиниција наводе у Речнику САНУ. Значај који кућа има за човека, а који се уградио у сему колективне експресије, проистиче пре свега из функционалних и друштвених аспеката куће, у којој човек остварује своје основне биолошке (храна, топлота) и психолошке (сигурност, интимност) потребе.

Анализа значењског садржаја лексеме кућа показала је да се овај појам често концептуализује као породица, а потврде за такав доживљај куће налазимо и у бројним фразеологизмима и устаљеним синтагматским спојевима: закопати (затворити, затрти, ископати, угасити и сл.) кућу $\rightarrow$ истребити, затрти, униитити породицу; бити од (на) куће $\rightarrow$ бити из добре, угледне породице; савити кућу $\rightarrow$ основати свој дом, породииу; велика кућа $\rightarrow$ многочлана, велика породица; стара кућа $\rightarrow$ породица која има друштвени углед већ више генеращија и сл. Дефиниције наведених фразеологизама и примери у којима су посведочени откривају нам да говорници са српског језичког подручја итекако воде рачуна о угледу своје породице у друштву (нпр. Све су то сојевићи, старе куће, како се то каже (Радул. Ј. 4,6)). Углед породице је од велике важности и када је избор супружника у питању (нпр. И од куће је био, па су се скупљале око юега ђевојке (Ђукић. Т. 1, 15); Моја снаха није имала порода. А ... од куће [je] u образа: жао ми је било да је роду испратим (Бож. Г. 3, 21)). Још један од културолошких података до којих се долази анализом фразеолошке грађе лексеме кућа јесте да припадници српског народа прелазак мушкарца у женину кућу након ступања у брак сматрају неприхватљивим понашањем: Ја сам жени у кућу ушао ... Србијании кажу уљез, Босанщи дошљо (Банов., Пол. 1959, 16479/9).

На ниподаштавајући однос које друштво има према женама указују бројни примери који се уз поједине фразеолошке јединице наводе: $O н$ иде од куће до куће, пије, доће својој кући, избије жену па тако из дана у дан (Доман. 6, 241); 
Цела је кућа на юој (Станк. Б. 2, 59); Е, да на юој кућа стоји, би је упропастила (Игњ. J. 8, 322). Примери које смо навели упућују и на концептуализацију куће као терета који најчешће пада на леђа жена.

За осветљавање куће са лингвокултуролошког становишта посебно је значајан фразем бити као код (своје) куће $\rightarrow$ добро се сналазити, осећати се слободно, угодно као у својој кући; бити добро примљен, прихваћен. Из наведеног фразеологизма сазнајемо да човек за своју кућу везује осећај слободе, сигурности, угодности, пријатности. Кућа је, пре свега, место у којем човек живи са својом породицом, простор у којем је заклоњен од спољашњег света, па се отуда и може слободно понашати. Из овога видимо да се кућа у српском језику концептуализује као оаза мира и слободе, из чега - између осталог - проистиче емотивни однос према њој. Важност слободе коју човек осећа код своје куће показује и фразеологизам са лексемом кућица: своја (моја, твоја и сл.) кућица своја (моја, твоја и сл.) слободица (слободичица, вољица) $\rightarrow$ сваком је најугодније, свак је најслободнији у својој кући, у свом дому. Емотивни однос који човек гаји према својој кући додатно је наглашен употребом хипокористика кућица. Међутим, овде се намеће и питање граница слободе, пошто фразеологизам осећати се/понашати се као код своје куће може имати и негативно значење - када се неко на одређеном месту не понаша примерено датим околностима, односно понаша се слободније него што то прилика изискује. ${ }^{5}$

Анализа фразеолошког фонда лексеме кућа открила нам је да овај појам у бројним фразеологизмима функционише и као параметар према којем се оцењује друштвено прихватљиво или неприхватљиво понашање (дићи, дизати кућу на главу $\rightarrow$ (на)правити галаму, неред; закопати, затворити, угасити и сл. кућу $\rightarrow$ истребити, затрти, угасити породииу; ићи од куће до куће $\rightarrow$ скитати се, шврљати; подупирати кућу одозго, с крова $\rightarrow$ наносити штету, упропашћавати и сл.) и према којем човек вреднује људе и појаве у свету који га окружује. Често се вредност човека пореди са вредношћу куће: кука (плаче) кућа за тобом (ьим и сл.) $\rightarrow$ каже се када је неко необично вредан, способан за нешто или кућа од куће $\rightarrow$ поуздан, поштен човек. Поред тога, кућа служи и као мера нечијег расположења: нису му (јој и сл.) све козе код куће $\rightarrow$ није расположен, не иде му све како је планирао и сл., као мера хитности: не гори (ти, му и сл.) кућа (над главом) $\rightarrow$ није (ти, му и сл.) хитно, није потребно да журиш (да журим и сл.); кућа му (ти и сл.) над главом гори (у пламену je) $\rightarrow$ веома му (ти и сл.) је хитно потребна помоћ; у тешком, опасном је (си и сл.) положају, или пак као мера уопште: с куће на кућу $\rightarrow$ просечно од куће, домаћинства, по домаћинству; до божје куће $\rightarrow$ до краја, до крајье границе, мере, до крајюих могућности; ближе кући $\rightarrow$ корисније, паметније; пиши кући пропало $\rightarrow$ нема лека, помоћи (чему). Чињеница да човек користи кућу као параметар вредновања света око себе још једном потврђује да кућа (заједно са по-

5 За више информација о концепту СЛОБОДЕ у српској лингвокултури исп. Р. Драгићевић (2013: 43-59). 
родицом која у њој живи) представља центар његовог света и једно од највећих богатстава које поседује.

Анализирајући фразеологизме у којима је лексема кућа управни члан, запазили смо важност опозиције отворено - затворено у вези са кућом. Важност ове опозиције није нимало случајна. Наиме, отворена кућа симболизује велику породицу, лозу која траје, кућу која врви од живота, која је пуна гостију, док, са друге стране, затворена кућа означава пропадање породице и гашење лозе (нпр. раскопати, растурити кућу; закопати, затрпати, затрети, угасити кућу). Фразеологизми држати (имати, водити) отворену кућу $\rightarrow$ paдо, много примати госте, посете, бити гостопримљив и отворити кућу $\rightarrow$ почети примати госте, посетиоче откривају нам и стереотипну представу о Србима као изузетно гостољубивом народу. Чињеница да је наш народ познат по томе да воли да угости посетиоце и покаже са као добар домаћин наталожила се у виду културног садржаја у наведеним фразеологизмима.

На крају можемо закључити да је изглед куће и овога пута, као и при формирању полисемантичке структуре, остао у другом плану, јер га језик - за разлику од човека - не сматра релевантним, већ акценат ставља на функционалне и аксиолошке аспекте куће. Људима, заправо, кућа није ни важна као физички објекат, већ као оно што суштински представља - топло и пријатно породично гнездо и егзистенцијалну сигурност. Фразеологизми нам, дакле, откривају да се кућа у српском језику концептуализује као породица, склониште, уточиште, слобода и потврђују да се овом појму приписују и хедонистичке вредности (нпр. удобност, опуштеност, пријатност и сл.). У фразеологизмима до пуног изражаја долазе управо важност куће и осећаји који се за њу везују.

2.3. Синоними лексеме кућа. Постојање великог броја синонима лексеме кућа у речницима српског језика није нимало случајно, већ представља одраз тежњи говорника да се што прецизније изражавају када говоре о тако важном појму као што је кућа. Како Р. Драгићевић наводи (2013: 45), оно што је битно, оно о чему се често говори и мисли мора наћи свој прецизан језички израз.

Миодраг Лалевић у речнику Синонима и других сродних речи српскохрватског језика наводи бројне синониме лексеме кућа: дом, колиба, конак; сувота; бина, брвнара, луба, лубница, плотара, плетер, бондручара, чардак, шумњача, плужина, превијача, савијача, пударица, савр(н)дак, огњарица, трница; поземљуша, приземљуша; страћ, страћара, бурдељ, кућер, кулача, кровиьара; чатрља у учера, учерица, дубирог, појата, трла, бусара, бусача, земунииа, ћумез, трап, стаја; кошара, јазбина, кокошарник, кокошиьаи, голубарник, свиьаи, штенара, барака, праг; оцак, дим, слеме и илеме, огањ, огњиште; кула, двор, двори, двораи, замак, палата, палача; домаћи кут; сојеница итд.

Наведене синониме, према начину на који ступају у синонимске односе са лексемом кућа и према аспекту који профилишу, разврстаћемо у неколико група.

2.3.1. Прва група синонима лексеме кућa. Прву групу чине синоними попут колиба, конак; сувота; бина, брвнара, луба, лубница, плотара, плетер, чардак, шумњача, плужина, пударица, савр(н)дак, огњарица, трница; потлеуша, 
страћара, бурдељ, кућер, кулача, кровињара; чатрља, учера, учерица, дубирог, кљора, бусара, земуница, ћумез, барака, кула, двор, двори, дворац, замак, палаma, палача, сојеница и сл. У питању су лексеме које профилишу физичке аспекте куће као „зграде”, односно откривају бројне физичке карактеристике куће (материјал од којег је изграђена, величину, спратност, изглед, специјалну намену одређеном профилу људи и сл.), удаљавајући се на тај начин од прототипичне представе куће. Тако, на пример, колиба је широк назив за различне привремене или мање куће од врло различитог материјала, најчешће од дасака, прућа и коља; плужина је чобанска колиба код тора; кулача је покрајинска реч за колибу; замак је господски двор на властелинском имаюу; поземљуша, приземљуша је мала, ниска кућа и сл. Дакле, све наведене лексеме означавају неку специјалну врсту куће, односно сужавају семантички простор лексеме кућа. Наиме, у дефиницији примарног значења ове лексеме наводи се само то да је кућа грађевински објекат, зграда за пребивање, становање или какву друштвену потребу, без икаквих додатних информација о њеним материјалним карактеристикама. Код ове врсте синонима се, напротив, управо на том аспекту инсистира. Синоними из ове групе су значајни због тога што у њиховом случају, за разлику од секундарних значења и фразеологизама, језик није занемарио изглед куће, већ је - напротив - изнашао посебне лексеме за најразличитије врсте кућа. Треба истаћи и то да су у синонимском односу примарна значења наведених лексема са примарним значењем именице кућа.

Већина синонима из ове групе профилише статусне аспекте појма куће, па их на основу тога можемо поделити у две групе:

(1) Прву групу чине синоними лексеме кућа који у свом семантичком садржају експлицитно (у самој дефиницији) или имплицитно (на основу материјала и сл.) садрже сему „трошности/дотрајалости/сиромаштва”, чиме се указује на одсуство осећања сигурности и топлине, која кућа иначе пружа: колиба, луба, лубница, лубюача, плотара, плетер, плетара, глада, плужина, превијача, савијача, пударица, савр(н)дак, сав(а)рдак, нагон, огњарица, трница, поземљуша, приземљуша, потлеуша, потлеушица, страћ, страћара, бурдељ, кућер, кулача, кровињара, чатрља, уцера, учерииа, дубирог, кљора, бусара, бусачица, бусарница, земуница, ћумез, барака, сојеница.

(2) Другу групу чине они синоними који - захваљујући томе што им је једна од семантичких компоненти лексичког значења и сема „богатства/лепоте/уређености" - упућују на концепт КУЋЕ као простора који пружа топлину и сигурност: двор, дворац, двори, палата, палача, кула, бина.

Занимљиво је да у језику има много више лексема које се односе на мале и трошне куће, него оних којима се именују раскошне и богате грађевине. То није случај само са лексемом кућа. Наиме, Р. Драгићевић је, анализирајући различите групе лексема које су повезане неком парадигматском везом, утврдила да, по правилу, овакве групе садрже убедљиво више чланова са негативном конота- 
цијом него оних са позитивном. Ауторка сматра да разлоге за ову појаву треба тражити у ванјезичкој стварности - у националној култури, у погледу на свет српског народа и у општој друштвеној клими у којој је све што је непожељно упадљивије од онога што је пожељно (исп. Драгићевић 2010: 115-124). Тако, на пример, у српском језику има далеко више придева који означавају непожељне него пожељне људске особине. Такође, приметно је више лексема које се односе на нерад него на рад и сл. Наведену тврдњу поткрепљују и синоними лексеме $\kappa y \hbar a$.

2.3.2. Друга група синонима лексеме кућа. Један од најпродуктивнијих начина за настајање синонима јесте стварање секундарних семантичких реализација (Драгићевић 2007: 250). Пример за ову тврдњу представља друга група синонима именице кућа, у чији састав улазе лексеме које примарно означавају грађевине намењене смештају одређених врста животиња, док у неком од својих секундарних значења могу означавати кућу: стаја, кошара, јазбина, кокошарник, кокошињац, голубарник, свињаи, штенара, појата, трла, слон. Тако, на пример, јазбина у секундарном значењу може означавати тесну, тамну просторију, а штенара, чије је примарно значење псећа кућица, у секундарном значењу може именовати просторију или кућииу у којој је ледено. С обзиром да у синонимски однос ступају примарно значење лексеме кућа и секундарна значења наведених именица, можемо закључити да овај тип синонима лексеме кућа представља пример неправе синонимије, остварљиве само у одређеном контексту. Синоними из ове групе, захваљујући семантичкој компоненти „тесно/тамно/влажно/ прљаво" упућују на одсуство пријатности и удобности које кућа пружа, чиме се број негативно конотираних синонима куће знатно увећава.

2.3.3. Трећа група синонима лексеме кућa. Посебну групу контекстуалних синонима именице кућа чине лексеме које примарно именују неки од делова куће, а тек секундарно, деловањем механизама синегдохе, развијају значење

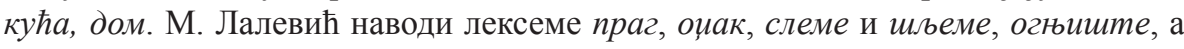
ми ћемо додати и врата, капија, кров и темељ. Ту су и лексеме дим и огањ, које не означавају делове куће, али су у логичкој вези са њом. Ова група синонима веома је важна за разумевање концепта КУЋЕ у српској лингвокултури, но кренимо редом.

Примарно значење лексеме праг јесте греда (од дрвета, камена или метала) која лежи с доње стране врата између довратника. ${ }^{6}$ Једна од важних семантичких компоненти примарног значења ове лексеме јесте сема позиције: праг се налази на улазу у кућу или неку од просторија унутар ње. Његова позиција је врло важна због тога што представља границу између два простора - сигурне унутрашњости куће и спољашњег света. Када означава кућу у целини, лексема праг сведочи о томе да је за концептуализацију куће у српском језику врло важна оштра одвојеност њене унутрашњости од спољашњег света, као и сигурност

${ }^{6}$ О развоју секундарних значења лексема које означавају делове куће пишемо на основу истраживања Р. Марковић (1991). 
која је захваљујући томе обезбеђена. Слично је и са лексемама капија и врата. Захваљујући својој граничној позицији на самом улазу у кућу, врата и капија остварују функцију повезивања, али и раздвајања кућног простора и спољашњег света.

Као један од синонима лексеме кућа функционише и именица кров. Већ из примарне семантичке реализацији ове лексеме - покривач, горюи део (обично нагнут или састављен од нагнутих површина) куће, зграде, грађевине уопште, који служи као заштита од временских непогода и сл. - јасно се види да је основна улога крова заштита унутрашњег простора куће и људи који у њему живе. Лексема кров можда најбоље од свих осталих синонима именице кућа сведочи о томе да се у нашем језику простор у којем човек живи са својом породицом концептуализује као склониште и уточиште. Да је заиста тако, потврђује и дефиниција која се уз значење 1.б. лексеме кров наводи у Речнику САНУ: као симбол куће и онога што она значи за човека: дом, кућа, склониште, место где се неко може склонити, сместити; уточиште, прибежиште (нпр. Ма шта се десило код мене ћеш увек наћи кров (Матк. 1, 53)). Потврду да кућа представља један од основних услова за живот налазимо у примеру Човек мора прво да осигура себи основне, елементарне услове егзистениије, исхрану, одело, огрев, кров над главом (Петр. В. 13, 488).

На кућу као егзистенцијалну основу и нешто без чега се не може упућује још један од синонима из ове групе - темељ. Фундаменталност темеља послужила је као асоцијативно извориште за повезивање са семантичким садржајем куће: као што кућа не може без темеља, тако ни човек не може без куће.

Будући да најтоплије и најпријатније било у просторији где се ложила ватра, огњиште је у прошлости било место око којег се породица најчешће окупљала и проводила највећи део времена, због чега ова лексема, онда када означава кућу у целини, носи изразито позитивну конотацију топлине и породичне блискости. Исту конотацију има и огањ када означава кућу. Ове две лексеме показују да се у националној култури српског народа кућа доживљава као топло породично гнездо и место које пружа љубав и спокој.

Синоними који кућу осветљавају с традиционално-културолошког аспекта јесу и оцак и дим. Наведене именице могу фигуративно означавати и кућу у целини, али и породицу, фамилију која у њој живи. Дим који из оџака излази симбол је живота у тој кући, знак да у њој има људи који ту живе, на основу чега се успоставља метонимијска веза између дима и саме куће.

Видимо, дакле, да поједине лексеме са основним значењем делова куће могу секундарно означавати и кућу у целости, при чему у том случају сваки од ових назива указује на одређене карактеристике концепта КУЋЕ (нпр. кров упућује на заштиту, огњиште на топлину, темељ на важност и сл.).

На крају, осврнућемо се кратко и на синониме које наводи П. Ћосић (2008: $385)$, а које М. Лалевић у свом синонимнику није забележио: стан, стамбена јединииа, станиште, боравиште, седиште, резидениија, место становања, пребивалиите, адреса, домаћинство, кут, легло, матица, гнездо, гајба, кућанство, 
кров над главом и сл. Примере попут стамбена јединица и место становаға не можемо уврстити у синониме, јер полазимо од становишта да у синонимском односу могу бити искључиво две лексеме, а не лексема и синтагма. Међу наведеним синонимима посебно је занимљива лексема гнездо, због тога што носи изразито позитивну конотацију, истичући у први план удобност, топлину и сигурност куће. Речник синонима П. Ћосића бележи и домовину као један од синонима лексеме кућа, а овај податак је врло важан јер показује да се кућа у српској лингвокултури концептуализује као родна груда, отаџбина. С. Ристић и И. Лазић-Коњик (2012) наводе још неке примере: зграда, грађевина, гарсоюера, дуплекс, петоспратница, вишеспратница, вила, саламара, плочара, брлог и сл. Иако смо навели преко стотину лексема које се у речницима и литератури наводе као одређена врста синонима лексеме кућа, сигурни смо да овај списак није коначан. Потреба људи да за сваки тип куће изнађе посебну лексему говори у прилог важности куће за човека. ${ }^{7}$

2.4. Деривати лексеме кућа. Речи из основног лексичког фонда, које представљају стожер лексичког система, по правилу имају најразвијенију полисемантичку структуру и највећи број деривата. Богата значењска структура и велики број деривата сведоче о њиховој уклопљености у лексички систем и о значају који им се придаје у вредносном систему носилаца српског језика. Р. Драгићевић (2013: 45) тврди да потреба за стварањем много нових речи од неке лексеме никада није случајна, већ је изазвана ванјезичким разлозима - оно што је важно мора наћи свој прецизан језички израз. Деривати су врло важан извор за истраживање концепта КУЋЕ, јер обилују културолошким подацима.

2.4.1. Деривационо гнездо лексеме кућа. Деривационо гнездо лексеме кућа, према подацима из Речника САНУ и Речника MC, броји преко 160 деривата, што несумњиво говори о важности статуса именице кућа у лексичком систему српског језика. Навешћемо неке од њих: кућан, кућаник, кућанин, кућаниияа, кућанички, кућанка, кућански, кућанство, кућање, кућар, кућара, кућарак, кућаран, кућарац, кућарење, кућарити, кућарић, кућарища, кућарка, кућарски, кућарство, кућати, кућеван, кућевић, кућевласник, кућевласница, кућевник, кућевница, кућевно, кућевност, кућегазда, кућегаздарииа, кућеглава, кућегосподар, кућедомаћин, кућедомаћииа, кућедомник, кућеник, кућење, кућепазитељ, кућепазитељиия, кућепазитељски, кућер, кућера, кућерак, кућерац, кућерача, кућерина, кућерица, кућерка, кућеритина, кућетак, кућетина, кућештина, кућехранитељ, кућина, кућити, кућица, кућиште, бескућник, бескућница, бескућниитво, бескућност, укућанин, окућница, покућство, покућански, раскућа, раскућити, скућити се, паликућа, распикућа, стокућа итд.

Анализом дефиниција деривата лексеме кућа и примера који су уз њих дати можемо доћи до врло драгоцених културолошких података, који нам могу по-

${ }^{7}$ Посебну врсту синонимског односа илуструје однос између лексема кућа и дом, исп. ГортанПремк 2004: 140-142; Ђуровић 2013. 
моћи да ближе упознамо вредносни систем српског народа и његову традицију и менталитет.

Важан податак представља чињеница да већина деривираних именица које се односе на особе има позитивну или неутралну конотацију. Деривати овог типа углавном се односе на особе које вредно раде и унапређују домаћинство, који воле породичан живот или који пак поседују богате куће, добри су домаћини, газде: кућаник - онај који је вредан, способан у домаћинству, добар домаћин; кућанииа - добра, вредна домаћица; кућевница - женско које је вредно, поштено и чуварно. Такође, и код придевских деривата лексеме кућа запажамо јачу тенденцију стварања лексема које именују пожељна својства: кућаран - који марљьиво ради у кући, у домаћинству; ућан - који има напредну, богату кућу, дом, домаћинство; кућеван-привржен кући, дому, домаћинству, вредан, способан у обављању кућних послова, у домаћинству, а исти је случај и са прилогом кућевно - на кућеван, кућни, домаћи начин, вредно, штедљиво, домаћински. Значај места које у патријархалном друштву заузимају добри домаћини и домаћице поткрепљен је и примерима: Права кућанка илити домаћица мора бити радна, итедна (Варош, Лукић Л., ЗНЖ 26, 105); кућеник је мушкараи који је умеман и трудољубив да привређује својој кући (Жупа, Милић); то може само човек радин и кућанин (Ћоп. 10, 116); Девојка му се допадне, добро је одгојена, кућаница (Даница 1863, 770); Нека се моја сиромамад свикне раду и кућевности; без тога нема поштењ а (Горан 3,85$)$.

Издвајањем придева и прилога употребљених у дефиницијама и примерима можемо добити слику прототипичног домаћина (и домаћице) у српском друштву: добар домаћин је вредан, радан, способан, поштен, штедљив, поседује напредну и богату кућу и привржен је својој породици.

Ови деривати пружају нам увид у то колико је у српском народу и његовој култури важно бити добар домаћин (домаћица), стећи сопствену кућу и велико имање, бити свој на своме (нпр. кућевласник, кућедомаћин, кућегосподар, кућегазда). На ову чињеницу упућују и глаголи из деривационог гнезда именице кућа: кућити (се), скућити (се), окућити (се) и сл. Оваквих деривата лексеме кућа у српском језику је далеко више него оних који упућују на недомаћинско понашање: распикућа, раскућа, паликућа.

О устројености патријархалног друштва сведочи нам и пример Мужу припада господство а жени кућанство (Богиш. 3, 272). Ово је један од многобројних примера који указују на родну неравноправност која у друштву постоји.

У деривационом гнезду именице кућа евидентан је велики број деминутивних и аугментативних изведеница (нпр. кућица, кућерак, кућерица, кућетак, кућетина, кућетерина, кућина итд.). Занимљиво је да у случају куће деминутиви чешће добијају негативну конотацију и означавају нешто мало, трошно, сиромашно и неугледно, док, са друге стране, аугментативи - због тога што означавају велике куће - носе позитивне конотације. На овај начин је у језику рефлектован значај величине и изгледа куће у ванјезичкој стварности. 
2.4.2. Дериват кућни. Један од најзначајнијих деривата лексеме кућа јесте придев кућни. Како бисмо стекли потпуну слику о значењу овог придева, навешћемо систем дефиниција којима је представљен у Речнику САНУ: 1.a. који се односи на кућу (1a), који припада кући (1a); б. који је одређен само за кућу, који се носи само по кући, домаћи (обично о одећи); 2.a. који се односи на кућу, дом, породични, домаћи; б. који се односи на ред, обичаје у кући, на живот у кући (у некој стамбеној згради, установи и сл.); в. који се обавља, врши, одржава, дешава у кругу куће, породице; домаћи; породични; г. који се ради, израђује, производи укући, у домаћинству, ручни, домаћи; д. који је одређен за кућу, који се користи у кући, домаћи; 3. који се односи на кућу (5), на сопствену земьу, домовину; 4. (уз називе животиња) који живи у кући, уз насељена места: миш, $\sim$ мушица, пас.

Већ на основу значења у којима се реализује, можемо закључити да је дериват кућни много више од обичног релационог придева који означава да нешто припада кући или се на њу односи. Његов полазни семантички садржај темељи се на кући као грађевинском објекту (што је и у самој дефиницији прецизирано упућивањем на значење 1.a. лексеме кућа), али се у секундарним реализацијама од њега све више удаљава и приближава кући као месту у којем човек живи са породицом и обавља различите послове. Да је тако, потврђују и синонимски делови дефиниција. Они нам сведоче о томе да као синоними лексеме кућни у секундарним значењима функционишу придеви домаћи и породични. Синоними $\kappa у ћ а$ и дом развијају, дакле, и придеве који су у синонимском односу: кућни и домаћи. Овај податак само потврђује јаку везу која између куће и дома постоји.

Да би смо добили ширу слику концептуализације придева кућни у српском језику, анализираћемо и податке из Асоиијативног речника српског језика, у којем је ова лексема била један од стимулуса. На узорку од 800 испитаника добијене су 152 различите реакције на задати стимулус кућни. Добијене реакције испитаника, распоређене по критеријуму фреквентности, изгледају овако: ред (145 пута), љубимац (83), домаћи (63), праг (55), савет (54), пријатељ (30), апарат (25), мир (19), пас (18), породични (16), породица, телефон (13), послови (11), дом (10), миш (9), буџет, притвор (8), апарати, биоскоп (7), мој (6) итд. Најфреквентније реакције потврђују да се придев кућни чешће везује за породицу и породични живот, него за кућу у значењу грађевинског објекта. Само једна од десет најчешћих реакција профилише кућу са физичког аспекта, односно означава један њен део (праг). Чињеница да је придев домаћи на трећем месту по учесталости потврђује његову чврсту синонимску везу са лексемом кућни и њихову близину у менталном лексикону. ${ }^{8}$

Поред релационог значења, придев кућни развија и бројна квалитативна значења, која конкретизују позитивна осећања и схватања везана за кућу, оцену кућне атмосфере, добро расположење њених станара (исп. Бартмињски 2011:

${ }^{8}$ Ипак, придеви кућни и домаћи нису заменљиви у свим контекстима: постоје само домаћи сир и домаћи задатак, али не и кућни сир и кућни задатак (исп. Марковић 1991: 61). 
225). Тако, на пример, кућна хаљина обично асоцира удобност и опуштеност, кућни пријатељь врло блиску особу, а кућни амбијент пријатну и топлу атмосферу. Поред тога, у Ћосићевом Речнику синонима се као блискозначнице придева кућни наводе лексеме приватни, староседелачки, аутохтони и изворни, на основу чега можемо закључити да семантика овог придева надилази оквире куће као зграде и проширује се на кућу у значењу домовина, завичај.

Да придев кућни конкретизује позитивна осећања везана за кућу, показују и реакције из Асочијативног речника: мир (19), топао (3), приватност, приватни, топли, топлина (2), искрени, миран, најлепши, опуштено, опуштеност, пријатно, припадност, присност, радост, сигурност, сложни, срећа, топлота (1). Овоме треба додати и друге лексеме које имају врло позитивну конотацију и буде пријатна осећања, а везене су за кућу: љубимац (83), пријатељ (30), породица (13), традиција, заједница (1). На основу лексема које су применом асоцијативних тестова добијене, могли бисмо саставити прототипични сценарио живота у кући: кућа је место где човек сложно живи са породиџом и дружи се са својим пријатељима, често има и кућног љубимца. У кући проналази свој мир, топлину и сигурност, има своју приватност, па може да се понаша опуштено. Када је код куће, у заједници, човек има осећај припадности и присности са укућанима, па је због тога срећан и радостан.

Да се не осећају сви пријатно и опуштено у кући, сведоче неке од асоцијација на придев кућни: притвор (8), затвор (3), досада, јед, казна, затворен (1). Концептуализација куће као затвора везује се пре свега за млађу популацију, која боравак у кући доживљава као казну и одсуство слободе. Овај податак потврђује и Двосмерни речник српског жаргона и жаргону сродних речи и израза Драгослава Андрића. Аутор наводи да се у омладинском жаргону кућом називају затвор, казнено-поправни дом и затворска самица, док се чуварем куће $у$ вечерњем периоду назива отац који не пушта кћер да излази увече. На основу свега наведеног можемо претпоставити да се концептуализација куће мења са годинама и сазревањем.

\section{3. Закључна разматрања}

Уколико желимо да упознамо дух и душу једног народа, први корак на том сложеном путу биће нам проучавање његовог језика и у њему ускладиштених културних информација. У језику се, током његовог историјског развоја, таложе различити културно конотирани садржаји и чувају веома старе представе и веровања, па се стога проучавањем језика може реконструисати слика света његових говорника. Језик, као живи организам, рефлектује све друштвене и културне промене једне говорне заједнице. Због тога смо, у жељи да откријемо како корисници српског језика схватају и доживљавају појам куће, истраживање лингвокултуролошки усмерили.

Већ сама чињеница да је лексема кућа у српском језику развила 26 семантичких реализација, преко 160 деривата и око 60 устаљених синтагматских 
спојева и фразеологизама говори у прилог важности појма њоме означеног у српској лингвокултуролошкој заједници, јер - као што је већ наглашено - оно што је говорницима битно, оно о чему често говоре и мисле мора наћи свој прецизан језички израз.

Системски (речнички) материјал лексеме кућа показао је да је говорницима српског језика на првом месту функционални аспект куће, али да језик ни њене физичке карактеристике (изглед и величину) није занемарио. Наиме, с једне стране, секундарне семантичке реализације регистроване у тезаурусном Речнику САНУ показују да се кућа превасходно концептуализује као симбол породице, породичне топлине и сигурности, као уточиште и склониште и оаза мира и слободе. На исте закључке упућују и фразеологизми који као један од конституената у свом саставу имају лексему кућа. С друге стране, деривати и синоними ове именице рефлектују значај величине и изгледа куће у ванјезичкој стварности. Већина забележених синонима описује управо неки од физичких карактеристика куће (нпр. материјал од којег је изграђена), док чињеница да деминутиви изведени од лексеме кућа чешће добијају негативну конотацију и означавају нешто мало, трошно, сиромашно и неугледно, док, са друге стране, аугментативи - због тога што означавају велике куће - носе позитивне конотације, показује да су ови изванјезички параметри итекако важни корисницима српског језика.

Поред тога, системски материјал именице кућа омогућио нам је да ближе упознамо менталитет српског народа, као и неке од његових ставова и стереотипа о појединим друштвеним појавама.

(1) На пример, открио нам је постојање амбивалентног односа према жени у српском друштву. С једне стране, евидентно је постојање стереотипа о подели улога у вођењу домаћинства и месту жене у патријархалном друштву, при чему се улога жене своди искључиво на обављање кућних послова. Са друге стране, међутим, неспоран је значај који жене имају за опстанак и просперитет сваке куће и домаћинства.

(2) Културолошки усмерена анализа деривата лексеме кућа пружа нам увид у то колико је српској култури важно бити добар домаћин, поседовати сопствену кућу и угледну породицу. На то нам првенствено указује податак да велики део деривационог гнезда лексеме кућа сачињавају лексеме које се односе на особе које вредно раде и уна-пређују домаћинство, које воле породични живот или које пак поседују богате куће, добри су домаћини, газде и сл. (нпр. кућаник, кућанин, кућаница, кућарииа, кућарка, кућаш, кућевласник, кућевласница, кућевић, кућевник, кућевница, кућегазда, кућегаздарица, кућеглава, кућегосподар итд.).

(3) Подаци добијени из речника српског језика указују и на важност очувања угледа породице у друштву, важност тог угледа при избору будућег супружника (као једног од најзначајнијих критеријума), али и негативан однос српског друштва према преласку мушкарца у женину кућу након ступања у брак. 
(4) Најзад, изрази попут држати (имати, водити) отворену кућу $\rightarrow$ paдо, много примати госте, посете, бити гостопримљив и отворити кућу $\rightarrow$ почети примати госте, посетиоце откривају нам још један важан културолошки податак: представу о Србима као изузетно гостољубивом народу. Чињеница да је наш народ познат по томе да воли да угости посетиоце и покаже се као добар домаћин наталожила се у виду културног садржаја у наведеним изразима.

\section{ЛИТЕРАТУРА}

Андрић 2005': Драгослав Андрић, Двосмерни речник српског жаргона и жаргону сродних речи и израза, Београд: Zepter Book World - Д. Андрић.

Бартмињски 2011: Јежи Бартмињски, Језик - слика - свет (приредио Д. Ајдачић, превела М. Бјелетић), Београд: SlovoSlavia.

Гортан-Премк 2004: Даринка Гортан-Премк, Полисемија и организащија лексичког система у српском језику, Београд: Завод за уџбенике и наставна средства.

Драгићевић 2007: Рајна Драгићевић, „Деривати у менталном лексикону”, Научни састанак слависта у Вукове дане, 36/1, 367-377.

Драгићевић 2007: Рајна Драгићевић, Лексикологија српског језика, Београд: Завод за уџбенике.

Драгићевић 2010: Рајна Драгићевић, Вербалне асоиијащије кроз српски језик, Београд: Друштво за српски језик и књижевност Србије.

Драгићевић 2013: Рајна Драгићевић, „Лингвокултуролошка анализа концепта слобода у српском језику и српској култури", Научни састанка слависта у Вукове дане, 42/3, 43-59.

Драгићевић и др. 2011: Рајна Драгићевић, Предраг Пипер, Марија Стефановић, Обратни асоиијативни речник српског језика: од реакиије ка стимулусу, Београд: Службени гласник - Београдска књига.

Ђуровић 2004: Сања Ђуровић, „Деривационо гнездо лексеме кућа: творбено-семантичка анализа", Наслеђе: часопис за књижевност, уметност и култуpy, год. I, број 1, 83-103.

Ђуровић 2013: Сања Ђуровић, „Синонимски пар кућа: дом у српском језику”, Српски језик, XVIII/I, 329-338.

Кликовац 2004: Душка Кликовац, Метафоре у мишььењу и језику, Београд: Библиотека XX век.

Лалевић 2004: Миодраг Лалевић, Синоними и сродне речи српскохрватскога језика, фототипско издање, Београд: Нолит.

Марковић 1991: Рајна Марковић, „Гранања значења речи које означавају кућу и њене делове”, Наи језик, XXIX/1-2, 55-76. 
Мршевић-Радовић 1987: Драгана Мршевић-Радовић, Фразеолошке глаголско-именичке синтагме у савременом српскохрватском језику, Београд: Филолошки факултет Београдског универзитета.

Мршевић-Радовић 2008: Драгана Мршевић-Радовић, Фразеологија и национална култура, Београд: Друштво за српски језик и књижевност Србије.

Оташевић 2007: Ђорђе Оташевић, Мали српски фразеолошки речник, Београд: Алма.

Пипер и др. 2005: Предраг Пипер, Рајна Драгићевић, Марија Стефановић, Асочијативни речник српског језика: од стимулуса ка реакиији, Београд: Београдска књига - Службени гласник СЦГ - Филолошки факултет у Београду.

Расулић 2004: Катарина Расулић, Језик и просторно искуство: Концептуализачија вертикалне димензије у енглеском и српскохрватском језику, Београд: Филолошки факултет Универзитета у Београду.

Речник МС: Речник српскохрватскога књижевног језика, т. I-VI, Нови Сад: Матица српска, 1967-1976.

Речник САНУ: Речник српскохрватског књижевног и народног језика, т. I-XVII, Београд: Српска академија наука и уметности, од 1959. године.

Ристић 2013a: Стана Ристић, Стереотип ДОМОВИНЕ у заједничкој концептосфери појмова ДОМА и МАЈКЕ, у: Зборник Матице српске за славистику (уредник Корнелија Ичин), број 83, Нови Сад: Матица српска, 181-198.

Ристић 2013б: Стана Ристић, „Стилски аспекти концептуализације појма ДОМ у књижевном дискурсу”, Научни састанак слависта у Вукове дане, 42/1, 381-394.

Ристић 2013в: Стана Ристић, „Концепт ДОМА у религијском дискурсу”, у: Теолингвстичка проучавања словенских језика. Тематски зборник (ур. Јасмина Грковић-Мејџор и Ксенија Кончаревић), Београд: Одељење језика и књижевности САНУ, 255-275.

Ристић и Лазић-Коњик 2012: Стана Ристић и Ивана Лазић-Коњик, „Дом у српском језику", www.rastko.rs/rastko/delo/14705 (27. 09. 2013).

PCJ: Речник српског књижевног језика, Нови Сад: Матица српска, 2007.

hосић 2008: Павле Ћосић и сарадници, Речник синонима, Београд: Kornet. 
Vesna S. Nikolić

\title{
LINGUO - CULTURAL IMAGE OF THE WORD HOUSE IN DICTIONARIES OF SERBIAN LANGUAGE
}

\begin{abstract}
Summary
The aim of the paper is to discover linguo - cultural image of the word house in Serbian cultural society, i.e. to determine which cultural information have accumulated in the semantic content of the lexeme house during its long lasting and frequent use through the analysis of systematic (lexical) material, which includes definitions, examples of use, synonyms, derivatives and phraseologisms. The analysis of the data from different dictionaries of Serbian language may uncover a great many information, not just about lexemes and their place in lexical system, but also about culture, mindset and attitude of its speakers. Thus, this paper simltaneously represents an example of using a monolingulal dictionary to linguo - cultural purposes.

Keywords: Serbian language, linguo - culturology, dictionaries, the lexeme house.
\end{abstract}

